\title{
French Colonialists' Investment in and Exploitation of Natural Rubber in Vietnam
}

\author{
Tuyen Mong Thi Nguyen \\ Department of Political Theory, Open University Ho Chi Minh City \\ 97 Vo Van Tan, 6th Ward, 3rd District, Ho Chi Minh City, Vietnam
}

Tel: 84-91-316-1817Ｅ-mail: tuyen.ntm@ou.edu.vn

Received: March 5, 2019 Accepted: April 8, 2019 Published: April 17, 2019

doi:10.5296/jad.v5i2.14675 URL: https://doi.org/10.5296/jad.v5i2.14675

\begin{abstract}
Rubber trees are among the plants which have sustainable economic values. In Vietnam, the discovery, cultivation and exploitation of rubber trees are closely associated with the natural formation and the historical upheavals of Vietnam as well as the world. Rubber was internationalized in the $18^{\text {th }}-19^{\text {th }}$ centuries and used extensively in the colonial industry of Vietnam during this period. This paper aims to provide insight into the importation and exploitation of rubber in Vietnam. Over 120 years of cultivating and exploiting rubber trees in Vietnam is the evidence of the plant's internalization, its significance in the capitalist economic development, and the proof of France's wisdom and economic strength. Upon this solid foundation, Vietnamese people today still preserve and continue developing rubber trees. The coverage of rubber trees in Vietnam focuses largely on the southeast part of the country, where fertile soil is ideal for perennial crops. Today, rubber growing and exploiting remains the backbone of Vietnamese economy, creating sustainable economic values. Through this paper, the author hopes to create a prospect for the internalization of Vietnamese rubber trees, contributing to the knowledge industry of the human kinds in the future.
\end{abstract}

Keywords: Rubber trees, investment, exploitation, cultivation, Vietnam, Indochina

\section{Introduction}

Since their first days in Vietnam, French colonialists managed to import rubber trees into the country but the trees' life span was too short. The official farming of rubber trees in Vietnam began in 1897 when Raoul, a pharmacist, brought 2000 rubber trees to Saigon Botanic Garden after his business trips to British colonies.

The cultivation of rubber trees in research gardens proved to bring about positive results. Evidently, in Nha Trang experimental garden - Thu Dau Mot research hub, Yersin - a scientist, 
and Vernent - an horticultural engineer (who had extensive research in rubber-related issues) found scientific groundings for the cultivation and tapping of rubber trees. After that, it was Yersin who had a prime role in establishing rubber sector in the South of Vietnam. Developing Yersin's research projects, French horticulturalists reached a conclusion that the agronomic and climatic conditions in the Southeast of Vietnam were favorable for the growth of rubber trees. Soon after, French capitalists quickly adopted those research findings in rubber commercialization in Indochina and in the South of Vietnam in particular. Since then, rubber trees have been native to basalt soil in Vietnam for over 100 years. During that period, together with the upheavals in the country's history, the rubber trees have also undergone several changes.

Rubber trading was vital for the existence of the French capitalists, so they made every attempt to possess the trees until 1975 when the South of Vietnam was completely freed from American imperialists. Only after this historical moment, rubber trees truly belonged to Vietnamese people.

\section{A brief History of Rubber Trees}

There are several species of rubber trees, of which the trees in Vietnam, scientifically known as Havea Brasiliensis, are the most superior species. The plants were indigenous to Brazil, a former colony of Portugal in Latin America.

In 1743, during their exploration of meridian and latitudes in Guyana, two French maritime officers, Fresnau $\mathrm{F}$ and De la Condamine $\mathrm{C}$ noticed a kind of deciduous trees. The trees had milky white sap, which became highly sticky, flexible, and elastic once condensed. Maina indigenous people to the south of Amazon used this sap to make bird trap and other daily items such as cups, containers, toys, and statues... These items were similar to what were found as the artifacts of Maya's culture in Latin America in the $11^{\text {th }}$ century.

Fresnau F. and De la Condamine C. drew a picture of this plant with full details about its flowers, leaves, fruits and nuts, etc. and sent it back to France to the Academy of Science. This is the very first image and knowledge about rubber trees. This discovery captured the attention of French public. Soon later, people started to use latex to produce water-resistant fibers. Since Charles Goodyear and Thomas Hancook discovered the vulcanization process in 1846 and, Michelin brothers invented removable pneumatic tire for automobiles in in 1890, rubber industry took off. Rubber trees became the leading industrial crops for capitalist corporations.

Fresnau F. and De la Condamine C. were also known as Western geographers who draw maritime maps for colonialism purpose of white people. Based on their first maps, rubber trees were brought to colonies of black and yellow people. For almost one century, this type of plant became a symbol of disaster, a cause of the miserable slavery life of people who lost their country.

The term RUBBER originated from Peru's indigenous language, in which caa means tree and $o$-chu means shedding tears or crying. Rubber is therefore the name of a plant that sheds tear or cries (Khang, Trung, \& Hien, 1979). 


\section{Rubber Trees in Vietnam}

In 1858, French colonialists attacked Da Nang to begin the invasion into Vietnam. Three years later, they seized the control of the South of Vietnam. Since 1884, when Patenotre treaty was signed between Nguyen dynasty and French colonialists, Vietnam became a half-colonized and half -feudalist country. It was the France' national policy was to colonize Vietnam in order to exploit natural resources and to turn it into a consuming market. In their policies, French people focused on agriculture. They planned to rob the farmers' land across the country and turn it into plantations that grow rice and perennial crops such as tea, coffee and rubber, etc. Until 1912, the land area for plantations occupied by the French mounted to 470,000 hectares, 308,000 hectares of which was in the South of Vietnam (Brenier, 1914).

During their colonist exploitation, the French soon recognized that harnessing agricultural products was not very profitable. Therefore, they enhanced researching and bringing scientists to live and work in Vietnam in order to examine natural resources and put forward long-term exploiting strategies.

Among the first scientists to Vietnam was J. B. Louis Pierre, a French botanist, who studied and imported several plants of high economic values into Vietnam, including rubber trees. In 1877, he experimented germinating rubber seeds in Sai Gon's Botanic Garden without success. It was because the number of seeds was small and very few trees that survived were cut off during the trimming of the garden.

In 1897, Paul Doumer, the governor general, established two research centers to germinate rubber trees from fresh seeds. One center was at Ong Yem experimental hub (Ben Cat - Thu Dau Mot) managed by E. Raoul, a pharmacist who studied tropical plants and one was at Suoi Dau, Nha Trang's Paster Institution, managed by Dr. A. Yersin. Most of the seeds were well germinated.

After that, young rubber trees and seeds were sent to grow on different types of soils in different places such as Go Vap, Thu Duc, Hue' s experimental research gardens, Tay Nguyen, and in the North of Vietnam. However, most of the trees soon died off due to inappropriate climatic and soil conditions.

In 1904, there was good news about growing rubber in Vietnam for the French. Growing rubber trees in the research gardens proved to be positive. Evidently, in Nha Trang experimental garden, Thu Dau Mot research hub, Yersin, the scientist, and Vernent, the horticultural engineer (who had extensive research in rubber problems) found scientific groundings for the cultivation and tapping of rubber trees. After that, it was Yersin who had a primary role in establishing rubber engineering in the South of Vietnam. Developing Yersin's research projects, French horticulturalists reached a conclusion that the agronomic and climatic condition in the Southeast of Vietnam was favorable for the growth of rubber trees, much as in the Amazon basin.

Soon after, French capitalists quickly adopted those research findings in rubber commercialization in Indochina in general and in the South of Vietnam in particular. Since then, rubber trees have been native to basalt soil in Vietnam for over 100 years. 
Rubber trees grow best in red and grey alluvial soil which constitutes a vast area in the South, running toward the north of Northeast and south of Southeast. That is highly fertile clay containing low level of lime, gravel or stone and high level of humus, which is consistent until 15-40 meters below the earth. This type of land well absorbs rainwater, remains moisture most of the time, neither being hardened nor creating flow of water. French scientists discovered that to the east of the South, the minimum area of basalt soil was 200,000 hectares, forming a stretch of land at $200 \mathrm{~km}$ long, and $2-20 \mathrm{~km}$ wide, an ideal condition for the growth of rubber trees. Especially in Thu Dau Mot, the area of rubber crops was three times larger than that of rice crops.

\section{French Colonialists' Investment in and Exploitation of Rubber (1858-1945)}

In order to gain huge profit from rubber, French capitalists made every attempt to appropriate the most fertile land. They issued a number of land stipulations to legalize their action. These stipulations complemented each other, with the latter enlarging their rights for land appropriation. For example, the Stipulation dated $9^{\text {th }}$ November 1886 stated that each French colonialist could only apply for less than 10 hectares of land for farming purposes. Yet, the Stipulation dated $6^{\text {th }}$ October 1889 and $15^{\text {th }}$ October 1890 could apply for even 500 hectares. Until 1918, the French occupied 184.700 hectares of land in the South, using 7000 hectares for rubber trees which produce 3000 tons of latex, primarily in the suburb of Sai Gon, in Thu Dau Mot and Bien Hoa provinces. Until 1945, the area for growing rubber trees was over 140,000 hectares, which produce over 80,000 tons of latex (The formation and development of Vietnam's rubber sector, 1997). During this time, rubber plantations were developed, giving birth to the rubber industry of French capitalists in Vietnam, particularly in the South of Vietnam.

Rubber trees distributed to French botanists stimulated several French people to grow rubber in the North of Sai Gon. One of the most noticeable examples was Phu Nhuan rubber plantation owned by Belland, a central police officer in Sai Gon, formed in 1898. After several trials, he succeeded in growing 15.300 trees over 45 hectares of land on his plantation. He started tapping 5000 8-year old trees, producing $1500 \mathrm{~kg}$ of latex in 1989 and 9500 7-9 year old trees, producing $3000 \mathrm{~kg}$ of latex in 1909 . He got $6000 \mathrm{~kg}$ of latex out of 10500 trees in 1910 , and $10000 \mathrm{~kg}$ of latex in 1911. The plantation had its own workshop to coagulate rubber. The coagulated rubber was packaged in the $100 \mathrm{~kg}$ containers, sent to be sold in Paris market at relatively high price of 13-22.7 Francs per $\mathrm{kg}$ while the production cost was only at 3 Francs and transportation cost was at 1 Francs per kg (Vinh, 2000).

In Suoi Dau (Nha Trang), Dr. A. Yersin released a good news in 1904 "The result of latex production in experiment was positive. The trees produced increasingly higher latex, up to $250 \mathrm{gr}$ of coagulated latex per tree and to $100 \mathrm{~kg}$ of coagulated latex totally to be sold at 1000 Francs" (Vinh, 2000, p. 32). The results from the two experimental hubs satisfied rubber growers that growing rubber trees would be lucrative.

The success stories of Mr. Belland and Dr. A. Yersin soon captured much of the public's attention. Since then, French capitalists and colonialist administration started to notice more about rubber trees, especially in the South of Vietnam. Rubber trees made their official 
presence in Vietnam as industrial crops. In the North, French government also established several rubber tree plantations but at small coverage area, and due to unfavorable weather condition, provided low yield.

At first, the French administration searched for fertile soils through different ways, such as disseminating religions, opening schools, bringing in troops to occupy land. These preliminary steps were to prepare for the colonialist ruling system, getting to know people's life and natural resources in order to proceed with the exploitation.

After penetrating into the new area of minor ethnic people, the French continued to establish troop territories and started to attack civilian population, enslaving local people, and using various tricks, ranging from deceiving to using armed forces to appropriate land, paddy fields, forests and habitats for building plantations or colons.

Of all 10 rubber corporations, the following ones had considerable investment and exploitation activities. Indochina plantation corporation (Société Indochinoise Des Plantations d' Hévéas, abbreviated as SIPH) was established in 1906 by Emile Girard, a French police officer who led and controlled it. Right after its formation, the company sought to expand by taking over and merging the adjacent plantations as well as under-invested ones. Such plantations as Dau Giay, Cam Tiem, Ong Que, An Loc, Dong Hap, Ben Cui, Gallia, Suzannah, La Souchere, Helena, Binh Loc, Cam My (Courtenay Plantation), Trang Bom, Cay Giao and Hang Gon were gradually under the control of SIPH. The company kept growing and, from 1914 to 1945, the number of workers employed by them increased to 350,000 people. The workers were local people, most of whom came from the North and Centre of Vietnam (Quang Binh, Thua Thien, Quang Nam, Da Nang). They were ordinary people, impoverished people, minor ethnic people who lost their land and had no livelihood.

During their first days, SIPH recruited men aged 18-25 but after 1930, with their growth, they employed all men, women, children of all ages for "low cost and high profit purpose". SIPH was supported by Indochina financial groups such as Indochina Bank, Indochina Corporation of Trade, Agriculture and Finance (abbreviated as SICAF) who consumed the products, regulated financial issues, provided money, and served as the patron of SIPH. Initial investment fund of SIPH was 30,000,000 Indochina units with 5,500 ha of rubber. The fund was doubled to $60,000,000$ with 9,900 ha of rubber in the South, producing an annual yield of 10,000 tons of coagulated latex. In addition to its strategic expansion, SIPH built up their strength by adopting flexible management techniques, availing the support of other forces, building agreement, protecting French people' rights and privileges. Until 1973, its rubber plantation area increased to 18,000 ha.

Red Land Plantation Corporation (Plantations des Terres Rouges, abbreviated as Terres Rouges, or SPTR) was founded in 1908 based on the mutual fund of Rivaud, a French capitalist, and Hallet, a Belgium capitalist. The company was financially backed and managed by the French administration, with its headquarter being based in Sai gon and its executive centre based in Quan Loi. After its formation, the company step by step expanded their plantations to include Xa Trach (in 1908) with 1,6135.5 ha, Xa Cam (in 1913) with 3,100.63 ha, Quan Loi (in 1916) with 5,372.35 ha, Xa Cat and later SPTR extended to other 
provinces such as in Bien Hoa (Long Thanh) and Ba Ria, and even to other countries including Cambodia (Binh Chan, Ngoc Bich, Ca Ret, Sa Mua, and particularly Chup plantation had a coverage of 24,000 ha), Java with 600 ha, Malaysia with 2.994 ha, and Sumatra with 4.043 ha Vinh, 2000).

SPTR had initial investment capital of 2,300,000 Francs, consisting of 23,000 shares of 100 Francs each. The fund rose dramatically to 36,000,000 Francs in 1923, 46,000,000 Francs in 1925, and 110,000,000 Francs in 1935. The company had built its own laboratory, and a research lab based in Bau Ong Yem (Thu Dau Mot province) to study the cultivation and production of rubber. The investment gave a high return of rubber, accounting for $35-40 \%$ of rubber in Indochina. SPTR was the biggest rubber corporation in Vietnam, recruiting workers from across the country. From 1914 to October 1955, the company had a total of 421,000 workers.

Far East Rubber Corporation (Société des Caoutechoues d'extrême-orient), known as CEXO, founded in 1911, was the merger between Indochina Rubber Corporation (Société des Caoutechoues de l'Indochine) and Indochina Corporation of Tropical Plants (Sociéte Indochine des Cultures Tropicales). The company was owned by De Laland, a French, and had its headquarter based in Paris. The company gradually expanded its territory: Locninh plantation (including Bu Dop plantation) was built in 1911 with 810 ha of rubber in Bu Dop plantation. It established another plantation in Xa Cat with an area of 3,500 ha in 1925 and two years later, another one in Minh Thanh with an area of 3,534 ha and Dakia with 10,000 ha. By 1929, with its own fund, CEXO had constructed $142 \mathrm{~km}$ railway connecting Loc Ninh with Sai Gon to serve Binh Long rubber region and Vietnam-Cambodia borderline.

Established 5 years after SIPH and 3 years after SPTR, CEXO had learnt considerably from their experience in recruiting workers. Worker recruitment offices were located in Thai Binh, Lang Son and Hai Phong provinces right in 1911. Pro-French mandarins were extremely helpful in recruiting workers. From 1925 to 1954 CEXO employed a total number of 218,000 workers (Lua, 1993). Initial investment capital of CEXO was quite huge: 1,500,000 Francs, consisting of 15,000 shares of 100 Francs. The fund grew on the yearly basis, with 4,500,000 Francs in 1912 to 6,000,000 Francs in 1917, 8,000,000 Francs in 1920 and 28,000,000 Francs in 1934 (Phong, 1963).

Michelin Plantation Corporation of Vietnam (Société des Plantations et Pneumatiques Michelin au Vietnam) was founded in 1917 by De Lafon, with its headquarter being based in Dau Tieng. The company had several major plantations: Dau Tieng (about 7,000 ha), Phu Rieng and Thuan Loi (about 3,000 ha). De Lafon built factories manufacturing pneumatic tyres for bicycles and motorbikes from latex produced by his plantations.

During the first few years, Michelin availed farmers during their free time, those who were "half worker, half farmers". These people constituted a large workforce but they had non-professional attitude and their time was not stable. As local farmers, they went to work in the plantations during non-farming periods and came back to their farm during the harvest time. 
Later on, the demand for workers rose significantly, Michelin began to recruit workers from other places. In order to avoid disputes with other giants, Michelin sought workers from Hanoi, Bac Giang provinces or those made redundant by other companies. From 1926 to 1954, a total of 260,000 workers were employed (Thanh, 1982). The employers applied harsh policies in managing workers. Michelin was widely known for its inhumane treatment of workers and there were continuously riots by the workers against the employers. After the mass riots by the workers from Phu Rieng plantation on 3rd February in 1930, Michelin merged Phu Rieng and Thuan Loi plantations into one, named as Thuan Loi in order for the public to forget the bloody event in Phu Rieng. In 1943, Michelin occupied 7\% of total rubber area and produced $11 \%$ of total rubber across Indochina.

Dong Nai rubber company (Le Caoutchouc du Dona, abbreviated as LCD), whose predecessor was Bien Hoa Forest and Engineering Company, was established in 1908, with its headquarter in Paris. The company focused on exploiting plantations of rubber, oil and bamboo plants in Indochina. Initial fund was 500,000 Francs, with 5,000 shares of 100 Francs. The fund kept growing to 2,000,000 Francs in 1911 and 6,000,000 Francs in 1919 [27;45]. In 1926, LCD started to exploit rubber trees and tapped 904 tons of latex. The amount of latex increased to 1,184 tons in 1939. The company continued to expand their plantations to include Trang Bom, Cay Giao, Tuc Trung. Total number of workers employed by LCD amounted to tens of thousands (Lua, 1993).

Tay Ninh Rubber Company was founded in 1908 by two brothers Jousset and Deleurance de Bellesme. From the initial 27 ha of rubber trees grown in Venven (Go Dau Ha), the company expanded its plantations to include Tra Vo, Hiep Thanh, Cau Khoi with a total area of 2,600 ha. Operated on its own funding, without any support from French banks, the company neither intended nor was capable of appropriating adjacent plantations. It hired labor from half-worker, half-farmer people in the local area.

Phuoc Hoa Rubber Company (Société des Caoutechoues de Phuoc Hoa) or Labbé Plantation (Plantation de Labbé) was founded and managed by a group of French capitalists, with its headquarter in Phuoc Hoa, Chau Thanh, Thu Dau Mot province. Labbé started exploiting since 1927 and its land area was gradually expanded to 2.000 ha until 1933, covering largely grey soil area and some red soil area.

Besides, there were small rubber companies founded by Vietnamese capitalists, Chinese people or pro- French people. 1931 statistics of Indochina rubber growers, there were about 60 owners of under 100 ha plantations (minor plantations), 12 companies with the plantation area ranging from 100-499 ha (medium plantations), most of those were authoritative figures such as Do Huu Tri, the judge, or Truong Van Ben, an industrial merchant, and Le Phat Tan, Vo Ha Thanh mandarin, Doan Huu Tung, Nguyen Van Yen - Head of Thu Dau Mot Treasure. There were not many Vietnamese farmers with less than 99 ha of rubber trees, most of whom inherited from their forefathers. They were hardly able to expand their plantation due to limited financial capacity as they could not obtain loans from French banks nor received any financial support from the French. They therefore had to run on their own funding. Moreover, in the war, these rubber areas belonged to the Vietnamese so the French attempted to destroy 
by shelling, bombing and bulldozing those areas that did not belong to their financial groups.

On the other hand, during the first decades of the $20^{\text {th }}$ century, the French administration did not have any policies to disseminate knowledge or provide support in order to encourage people to grow rubber. Local land owners therefore persisted in their traditional practices of buying rice paddies, hiring land, collecting taxes, lending money, buying early rice, etc. Few people would think about developing rubber plantations, which was not familiar to them. Some young Vietnamese capitalists did not have much funding and even if they had, they would rather follow their forefathers' traditions as a forementioned than invest money in growing and exploiting rubber. Moreover, as a colony of French, most of the land for growing rubber was under the control of the French.

Prior to the First World War, the investment of French companies in rubber industry kept growing but the majority of rubber trees were planted as trial, therefore the area for growing rubber was small and the yield was low. After the war, both France and Europe were thirsty for raw materials for manufacturing to restore the countries and the need for natural rubber was climbing. In order to compensate for the loss during the war, the French made massive investment in rubber corporations in Vietnam, and it was the national policy to expand the rubber plantation areas as well as rubber exploitation.

For instance, SPTR's investment fund increased dramatically over the year from initial 2,300,000 Francs (including 23,000 shares of 100 Francs each), to 36,000,000 Francs in 1923, 46,000,000 Francs in 1925 and 110,000,000 Francs in 1935. Similarly, CEXO's funding went up from 1,500,000 Francs (including 15000 shares of 100 Francs each) to 4,500,000 Francs in 1912, 6,000,000 Francs in 1917, 8,000,000 Francs in 1934 and 28,000,000 Francs in 1934. Along with the escalating fund, the land area for growing rubber expanded significantly.

Table 1. Rubber plantation area and yield of latex in the South from 1920-1945.

\begin{tabular}{lll}
\hline Year & $\begin{array}{l}\text { Land area } \\
\text { (ha) }\end{array}$ & $\begin{array}{l}\text { Yield } \\
\text { (tons) }\end{array}$ \\
\hline 1920 & 70.007 & 3.000 \\
1925 & 73.100 & 8.000 \\
1930 & 80.000 & 14.000 \\
1935 & 97.300 & 35.000 \\
1940 & 104.100 & 58.000 \\
1945 & 138.400 & 77.400 \\
\hline
\end{tabular}

Source: Vietnam General Corporation of Rubber (1997).

Rubber trading was extremely lucrative, especially during the years prior to Second World War when rubber price on the international market rocketed. A typical example was Xuan Loc Rubber company: with its initial investment of 360,000 Indochina monetary units, the company obtained a profit of 4,193,000 Franc in 1937 and more than doubled to 8,838,000 Francs the next year. 
With the rapid development of rubber sector in Indochina, primarily in Vietnam, rubber products made up a large proportion of export revenues in Indochina: 14,3\% in 1936 to $18 \%$ in 1937 , to more than a fifth $(21.4 \%)$ in 1938 and eventually more than one forth $(27,4 \%)$ in 1939. As a result, Vietnamese economy had a large trade surplus during this time. Rubber export in 1939 increased more than eight times from 1929 from 11,000,000 Francs to 96,000,000 Francs (Robequain, 1939)

The rapid development of rubber plantations created urgent demand for laborers. For the purpose of employing a large number of workers, the French colonialists made use of every barbarian strategies. Desrousseaux in one secret report to Indochina Governor Manager wrote: "Farmers would only leave their village and work when they were hungry. Therefore, it is not weird to conclude that the best remedy for the urgent need of workers is to impoverish them, withdrawing allowances and devaluing agricultural produces" (Phong, 1963, p. 23).

Robbing farmers of land and imposing heavy taxes in the North were not as cruel as breaking dykes in order to push them to the corner, depriving them of any livelihood. The extent of cruelty by the French colonialists was highlighted by Tran Van Giau, a historian, in the work "Vietnamese working class" by citing the French colonialists. A French ambassador in Son Tay, in a secret reported noted that: "In Vinh Yen, people from all walks of life were extremely frustrated and depressed because of continuous crop losses through the years. People complained about the government's breaking of the dyke in 1896 as the dyke was built by them for preventing flood. They therefore were infuriated. I have repeatedly reported on this" (Giau, 1979, p. 204). Hay Bonafond in his book "Thirty years in the North of Vietnam" wrote: "Oh my god! Is there anywhere in the world where they are so cruel like here. They easily decided to deluge a whole region under almost 1 meter during the whole 5 months. Any people, even the most barbarian one, could not do that!" (Hay Bonafond cited in Giau, 1979, p. 204)

The development of rubber plantations was closely associated with the process of exploiting Vietnamese labor. Workers were not just forced but exploited for economic surplus. In Red Land Rubber Corporation, in 1936, each worker produced about 12, 000 - 13,000 Francs but was paid only 1000 Francs per year. In 1939, 19 rubber companies gained a total profit of 309,000,000 Francs while paid a total amount of only 40,000,000 Francs to workers (Lua, 1993).

Rubber capitalists, for profit purposes, used various inhumane strategies to exploit labor such as: overtime working hours, enhancing work intensity, use of child labor, underpayment, etc. There was a deep divide in the social structure. On the one end, there were company owners who represented the upper class and lived a luxury life; on the other end, there were workers who got a living out of their own labor but led an impoverished life. Products and profits produced by workers went to the owners and giant capitalist groups. Laborers worked and lived in so harsh conditions and led a so-called "grim life". The capitalists' cruel exploitation drove rubber workers in Vietnam to rise and fight for the liberalization of themselves as well as the whole country. 


\section{Conclusion}

After Charles Goodyear found a method of vulcanizing rubber, rubber began to serve the indispensible needs of people, from clothes, shoes and other footwear products. From the $19^{\text {th }}$ century, rubber was increasingly used with the invention of bicycles and automobiles. Since then, it became the fourth most important material in the civilized world.

When the French started to exploit Vietnam (since 1897), with the successful germination of rubber seeds in Ong Yem garden (Lai Khe, Ben Cat, Thu Dau Mot province), rubber trees made its official presentation in Vietnam. Thirteen years later (in 1910), after major successes in the experiment process, rubber trees became one of the most important commercial plants.

Along with the mass establishment of rubber plantations in Vietnam, largely in the southeast of the country, private capitalist economic sector started to develop vigorously in the field of agricultural sector. The production and exploitation of rubber took off and played an important part in the south in particular and in the whole country in general under the French control.

Together with rice, tea and coffee, rubber has been one of the significant agricultural products for export so far. Under the French colonialism, the production, exploitation and export of rubber used to be the stimulus for the commercial-industrial economy of Vietnam, the driver of socio-economic development for the south of Indochina. Today, rubber trees remain the primary industrial plant and Vietnamese rubber workers still constitute the core workforce, pioneering in economic, political, cultural and social development.

\section{References}

Brenier, H. (1914). Essai d'Atlas Statistiques de L'indochine Francaise [Atlas Essay Statistics of French Indochina]. I.D.E.O Hanoi.

Giau, T. V. (1979). Vietnamese worker class. Hanoi: Truth Publishing House.

Khang, T. N., Trung, T. B., \& Hien, N. X. (1979). Rubber trees. Hanoi: Publishing House of Science and Technology.

Lua, H. (1993). History of Vietnamese rubber workers (1906-1990). Hanoi: Youth Publishing House.

Phong, N. (1963). French capitalists and rubber issues in Vietnam. Hanoi: Science Publishing House.

Thanh, N. (1982). Revolutionary movement of rubber workers in the Southeast of Vietnam. Hanoi: Labour Publishing House.

Vietnam General Corporation of Rubber. (1997). History of Vietnam's rubber sector. Vietnam Rubber Journal, 58-59, 50-51.

Vinh, D. V. (2000). 100 years of rubber trees in Vietnam. Ho Chi Minh City: Agricultural Publishing House. 


\section{Macrothink}

Journal of Asian Development

ISSN 2377-9594 2019, Vol. 5, No. 2

Robequain, C. H. (1939). Lévolution économique de L'Indochine Francaise [The economic evolution of French Indochina]. Paris.

\section{Copyright Disclaimer}

Copyright for this article is retained by the author(s), with first publication rights granted to the journal.

This is an open-access article distributed under the terms and conditions of the Creative Commons Attribution license (http://creativecommons.org/licenses/by/3.0/). 